\title{
BIOREMEDIASI MERKURI MENGGUNAKAN BAKTERI INDIGENOUS DARI LIMBAH PENAMBANGAN EMAS DI TUMPANG PITU, BANYUWANGI
}

\section{Mercury Bioremediation Using Indigenous Bacterial from Gold Mining Waste in Tumpang Pitu, Banyuwangi}

\author{
Saundra Rosallina Lutfi ${ }^{1 *}$, Wignyanto ${ }^{2}$, Evi Kurniati ${ }^{3}$ \\ ${ }^{1,2}$ Jurusan Teknologi Industri Pertanian - Fakultas Teknologi Pertanian - Universitas Brawijaya \\ Jalan Veteran, Malang 65145 \\ ${ }^{3}$ Jurusan Keteknikan Pertanian - Fakultas Teknologi Pertanian - Universitas Brawijaya \\ Jalan Veteran, Malang 65145 \\ *Penulis Korespondensi: email: saundra241293@gmail.com
}

\begin{abstract}
ABSTRAK
Limbah merkuri merupakan suatu limbah berbahaya yang sering digunakan sebagai proses amalgamasi dalam penambangan emas. Dampak dari merkuri akan semakin meningkat terlebih para penambang tidak pernah mengolah limbah merkuri tersebut sebelum dibuang ke lingkungan, sehingga diperlukan suatu metode untuk menjadikan limbah merkuri tersebut tidak beracun atau bahkan hilang. Salah satu metode yang dapat dilakukan yaitu melakukan proses bioremediasi. Pada penelitian ini, proses bioremediasi dilakukan dengan menggunakan bakteri indigenous yang diisolasi dari limbah penambangan emas Tumpang Pitu, Banyuwangi. Bakteri indigenous tersebut didapatkan dengan mengambil sampel berupa sedimen dan sampel cair dari penambangan emas, dan kemudian dilakukan proses isolasi dan seleksi menggunakan merkuri dengan kadar 0-130 ppm. Proses ini untuk mendapatkan bakteri yang resisten terhadap kadar merkuri tertinggi dan mampu untuk melakukan proses degradasi merkuri terbaik. Selanjutnya, dilakukan proses identifikasi bakteri yang terbukti mampu untuk melakukan proses bioremediasi. Penelitian ini memiliki tujuan untuk mendapatkan bakteri indigenous dari limbah penambangan emas pada proses bioremediasi limbah merkuri di suatu lingkungan sehingga tidak berbahaya bagi lingkungan. Hasil penelitian menunjukkan bahwa bakteri jenis Morganella morganii yang resisten terhadap merkuri dan mampu melakukan bioremediasi merkuri hingga mencapai $92.46 \%$
\end{abstract}

Kata kunci : Bioremediasi, Isolasi Bakteri, Merkuri, Morganella morganii

\section{ABSTRACT}

Mercury waste is a hazardous waste that often used as an amalgamation process in gold mining. Impact from mercury will increase, especially a miner never to process mercury waste before it is discharged into the environment, so the method is needed to make the mercury waste can non-toxic or even lost. One method that can be done is doing bioremediation process. In this research, bioremediation process was done by using indigenous bacteria isolated from Tumpang Pitu gold mining waste, Banyuwangi. To get the bacteria Indigenous samples taken in the form of sediment samples and liquid samples from gold mining and then processed isolation and selection using mercury with levels of 0-130 ppm. This process is to obtain bacteria that are resistant to the highest mercury levels and are able to perform the best mercury degradation process. Then carried out the identification process of bacteria that proved able to perform bioremediation process. This study aims to obtain indigenous bacteria from gold mining waste for bioremediation process of mercury waste in an environment so as not to be harmful to the environment. It was found that Morganella morganii bacteria were resistant to mercury and able to do mercury bioremediation up to $92.46 \%$

Keywords : Bioremediation, Bacteria Isolation, Mercury, Morganella morganii 


\section{PENDAHULUAN}

Indonesia merupakan negara yang memiliki cadangan sumber daya emas besar (Fachri, 2005; Supit, 2009; Karmanto et al., 2013), dimana salah satu lokasinya terletak di Tumpang Pitu, Kabupaten Banyuwangi, Jawa Timur (Setiawan, 2017). Namun pada proses penambangannya digunakan proses ekstraksi yang berbahaya baik bagi lingkungan maupun makhluk hidup, yaitu menggunakan logam merkuri untuk proses amalgamasi karena biaya yang dikeluarkan relatif rendah (Davies, 2014).

Hasil analisis kandungan merkuri pada penelitian sebelumnya oleh Siahaan et al. (2014) di desa Pesanggaran, kecamatan Genteng, kabupaten Banyuwangi sebesar $38.01 \mathrm{ppm}$ yang merupakan penambangan terdekat dengan penambangan Tumpang Pitu. Pada daerah Tumpang Pitu belum terdapat data kandungan merkuri. Jumlah tersebut sangat melebihi ambang batas limbah yang mengandung merkuri menurut Menteri Lingkungan Hidup (2004) yaitu sebesar 0.005 ppm. Tingginya kadar merkuri tersebut, dimungkinkan akan tertinggal di lingkungan dan sangat sulit untuk terdegradasi, yang menjadi fokus utama apabila pertambangan tersebut sudah berjalan beberapa tahun (Kocman et al., 2014), dikarenakan logam merkuri dapat masuk dan mengendap di dalam tanah dan air yang kemudian dapat masuk ke rantai makanan makhluk hidup (Sinha dan Paul, 2014; Huber dan Leopold, 2016; Kim et al., 2016; Oliveira et al., 2016).

Bahaya lain dari merkuri yaitu menyebabkan keracunan sistem syaraf dan gangguan fungsi pernafasan pada manusia serta merusak ekosistem sungai, persediaan makanan bagi manusia yang tinggal di lingkungan perairan tercemar merkuri (Rifai-Hasan, 2009; Hamann et al., 2014; Ma et al., 2014; Molamohyeddin et al., 2017). Pada proses degradasi pencemar yang masuk, lingkungan sebenarnya dapat mendegradasinya melalui proses biologis dan kimiawi, namun karena beban pencemarannya lebih besar, maka perlu adanya campur tangan manusia (Nasikhin dan Sofitri, 2013). Salah satunya yaitu dengan metode bioremediasi yang merupakan proses pengilangan merkuri yang ramah lingkungan dan tidak mahal (Mahbub et al., 2016; Broszeit et al., 2016; Dash et al., 2017; Kurniati et al., 2014; Peng et al., 2017; McCarthy et al., 2017).
Bioremediasi merupakan metode ramah lingkungan karena memanfaatkan bakteri (Hema et al., 2014; Sharma et al., 2018). Bakteri dapat hidup di lingkungan dengan konsentrasi logam berat yang tinggi dan dapat mendegradasi limbah beracun dalam lingkungan. Namun untuk mendapatkan bakteri tersebut perlu dilakukan tahapan awal yaitu proses isolasi, seleksi, dan dilanjutkan dengan proses karakterisasi dan identifikasi, sehingga tujuan penelitian ini adalah dapat melakukan proses isolasi, seleksi, karakterisasi, dan identifikasi.

\section{BAHAN DAN METODE}

\section{Bahan}

Bahan utama yang digunakan dalam penelitian ini adalah sampel air limbah yang diperoleh dari Tailing Tambang Emas Banyuwangi Jawa Timur, tisu, kertas payung, karet, kapas, plastik wrap, aluminium foil, masker, sarung tangan, spidol marker, larutan standar merkuri, aquades, spiritus, alkohol $70 \%$, plastik tebal berperekat, $\mathrm{HCl}, \mathrm{NaOH}, \mathrm{HNO}_{3}$. Selain itu, bahan media yang dibutuhkan adalah Luria Bertani (LB), Agar, glukosa, sukrosa, pepton, $\mathrm{NaCl}, \mathrm{HgCl}_{2}$ produksi Merck Jerman, serta reagen untuk uji Gram positif dan negatif.

\begin{abstract}
Alat
Alat yang digunakan dalam penelitian antara lain Laminar Air Flow dengan merk lokal, autoklaf dengan merk Hirayama HVE50 , oven dengan merk Memmert, cawan Petri dengan merek pyrex, tabung reaksi dengan merek pyrex, inkubator dengan merk Memmert Churt, pipet ukur dengan merk pyrex, lemari es dengan merk LG, jarum ose, neraca digital dengan merk sartorius, Beaker glass dengan merk pyrex, spatula, Erlenmeyer dengan merk pyrex, gelas ukur dengan merk pyrex, labu ukur dengan merek pyrex, mikropipet dengan merk Accumax pro.

Alat yang digunakan untuk analisis yaitu mikroskop cahaya dengan merek Yazumi, pH meter dengan merk Eutech, satu set alat AAS (Atomic Absorption Spectrophotometer) merk Shimadzu AA-6200, kaca preparat, object glass, Bunsen, serta kit microbact.
\end{abstract}

\section{MetodePengambilan Sampel}

Sampel Limbah Penambangan emas 
yang diambil terletak di Tumpang Pitu, Banyuwangi. Prosedur dan teknik pengambilan sampel berdasarkan Mahbub et al. (2016), yaitu Ditentukan tiga lokasi yang akan diambil sampelnya, kemudian diambil sampel cair yang diambil berjumlah masingmasing 0.5 liter dan sampel sedimen $250 \mathrm{~g}$ dan dimasukkan ke dalam plastik tebal berperekat, dilakukan analisis kadar $\mathrm{pH}$, kadar merkuri, serta pengamatan warna dan bau, dan dimasukkan ke dalam lemari pendingin selama penelitian berlangsung.

\section{Isolasi Bakteri}

Isolasi bakteri berdasarkan Pepi et al. (2011) yang pertama dilakukan yaitu menyiapkan sampel sedimen dan sampel cair dari limbah tambang emas. Kedua jenis sampel tersebut kemudian ditimbang dengan berat sampel sedimen $1 \mathrm{~g}$ dan sampel cair $1 \mathrm{ml}$. Selanjutnya, dilakukan pengenceran menggunakan aquades dengan faktor pengenceran sebesar $10^{-3}$. Diambil sebanyak $0.1 \mathrm{ml}$ dari pengenceran $10^{-3}$, kemudian sebanyak $0.1 \mathrm{ml}$ yang diambil dari pengenceran tersebut dimasukkan dalam media Luria Bertani yang telah ditambahkan merkuri yang diambil dari persediaan merkuri yang telah dibuat sebelumnya. Adapun kadar merkuri awal yang digunakan untuk proses isolasi adalah merkuri tertinggi di sedimen pembuangan tambang emas Tumpang Pitu. Setelah itu dilakukan inkubasi selama 2 × 24 jam dengan suhu $26{ }^{\circ} \mathrm{C}$. Apabila bakteri dapat tumbuh pada kadar tersebut, konsentrasi merkuri ditingkatkan terus hingga kadar tertinggi merkuri yang dapat ditumbuhi bakteri.

\section{Seleksi Bakteri Pereduksi Merkuri}

Setelah dilakukan proses isolasi, kemudian bakteri resisten merkuri diuji kemampuannya dalam melakukan reduksi merkuri. Tahapan yang dilakukan yaitu menyiapkan media LB yang dicampur dengan $\mathrm{HgCl}_{2}$ dalam 2 tabung yang berbeda. Salah satu dari 2 tabung tersebut dicampur dengan $0.1 \mathrm{ml}$ suspensi limbah yang telah dibuat sebelumnya. Campuran dari media $\mathrm{LB}, \mathrm{HgCl}_{2}$ dan suspensi limbah tersebut kemudian diinkubasi selama 2 × 24 jam dengan suhu 26 ${ }^{\circ} \mathrm{C}$, Kemudian kedua tabung tersebut dianalisis menggunakan AAS (Atomic Absorption Spectrophotmeter). Hasil akhirnya diketahui perbandingan antara media $\mathrm{LB}$ dan $\mathrm{HgCl}_{2}$ dengan media $\mathrm{LB}+\mathrm{HgCl}_{2}+0.1 \mathrm{ml}$ suspensi atau mengetahui perbandingan media LB dan $\mathrm{HgCl}_{2}$ sebelum dan sesudah dilakukan inokulasi dengan $0.1 \mathrm{ml}$ suspensi limbah.

Karakterisasi dan Identifikasi Isolat Bakteri Langkah selanjutnya adalah melakukan karakterisasi dan identifikasi isolat bakteri seperti yang dilakukan oleh Neneng (2007), untuk mengetahui jenis bakteri maka dilakukan identifikasi menggunakan microbact kit. Microbact kit adalah suatu alat yang digunakan unuk mengidentifikasi bakteri dengan melihat hasil parameter-parameter yang ada dan dimasukkan dalam sistem untuk mengetahui jenis bakteri yang diidentifikasi.

Tahapan dalam penggunaan microbact kit adalah isolat murni yang telah didapat, ditanam, disiapkan, kemudian ditumbuhkan pada media Luria Agar dan diinkubasi selama 24 jam pada suhu $37^{\circ} \mathrm{C}$. Setelah diinkubasi, sebanyak 1-5 koloni murni diambil dari media agar. Selanjutnya, ditambahkan laru$\tan 5 \mathrm{ml} \mathrm{NaCl}$ fisiologis $0.85 \%$. Larutan $\mathrm{NaCl}$ yang berisi sel bakteri tersebut kemudian dimasukkan dalam sumur Microbact Kit dimana setiap sumuran diisi $200 \mu$ l. Lempeng microbact kit selanjutnya diinkubasi dalam waktu 12-18 jam dengan suhu $37^{\circ} \mathrm{C}$. Setelah dilakukan inkubasi, dilakukan pembacaan hasil reaksi yang tampak pada lempeng microbact kit.

\section{HASIL DAN PEMBAHASAN}

\section{Hasil Isolasi Bakteri}

Berdasarkan Tabel 1 dapat dilihat bahwa karakteristik limbah penambangan emas memiliki karakteristik yang berbeda satu dengan yang lain. Berdasarkan Tabel 1, pada parameter hasil analisis kadar merkuri yang ada pada limbah penambangan emas Tumpang pitu, Banyuwangi, kadarnya melebihi ambang batas standar mutu yang telah ditetapkan oleh pemerintah dimana kadar terendah adalah 0.031 ppm pada limbah cair 1 dan yang tertinggi adalah 0.063 ppm pada limbah sedimen 2 . Limbah sedimen memiliki kadar merkuri yang lebih tinggi bila dibandingkan dengan limbah cair karena pada limbah sedimen logam merkuri yang digunakan akan terakumulasi di dalam tanah dan tidak mampu untuk didegradasi oleh lingkungan sehingga kadarnya akan tinggi. Kadar yang 
Jurnal Teknologi Pertanian Vol. 19 No. 1 [April 2018] 15-24

Bioremediasi Merkuri Menggunakan Bakteri Indigenous [Lutfi dkk]

Tabel 1. Karakteristik limbah penambangan emas Tumpang Pitu

\begin{tabular}{|c|c|c|c|c|c|c|}
\hline \multirow{3}{*}{ No. } & \multirow{3}{*}{$\begin{array}{l}\text { Jenis } \\
\text { Sampel }\end{array}$} & \multicolumn{5}{|c|}{ Parameter } \\
\hline & & \multicolumn{2}{|c|}{ Kadar Merkuri (ppm) } & \multirow[b]{2}{*}{$\mathrm{pH}$} & \multirow[b]{2}{*}{ Warna } & \multirow[b]{2}{*}{ Bau } \\
\hline & & $\begin{array}{c}\text { Hasil } \\
\text { Analisis }\end{array}$ & $\begin{array}{l}\text { Standar } \\
\text { Mutu* }^{*}\end{array}$ & & & \\
\hline 1. & Sedimen 1 & 0.054 & \multirow{6}{*}{$\begin{array}{l}0.002- \\
0.005\end{array}$} & 7.58 & Coklat & $\begin{array}{l}\text { Bau lumpur } \\
\text { agak menyengat }\end{array}$ \\
\hline 2. & Sedimen 2 & 0.063 & & 7.47 & Coklat & $\begin{array}{l}\text { Bau lumpur } \\
\text { agak menyengat }\end{array}$ \\
\hline 3. & Sedimen 3 & 0.033 & & 7.64 & Coklat & Bau lumpur \\
\hline 4. & Cair 1 & 0.031 & & 8.13 & Agak coklat & Tak Berbau \\
\hline 5. & Cair 2 & 0.043 & & 8.05 & Agak coklat & $\begin{array}{l}\text { Bau agak } \\
\text { menyengat }\end{array}$ \\
\hline 6. & Cair 3 & 0.034 & & 8.32 & Agak coklat & Tak Berbau \\
\hline
\end{tabular}

Tabel 2. Tingkat kekeruhan di media Luria Bertani yang diberi merkuri

\begin{tabular}{clccccccccccccc}
\hline \multirow{2}{*}{ No. } & Sampel & \multicolumn{10}{c}{ Konsentrasi Merkuri pada Media LB (ppm) } \\
\cline { 2 - 12 } & & $\mathbf{0}$ & $\mathbf{5}$ & $\mathbf{1 0}$ & $\mathbf{1 5}$ & $\mathbf{2 0}$ & $\mathbf{5 0}$ & $\mathbf{1 0 0}$ & $\mathbf{1 2 0}$ & $\mathbf{1 3 0}$ & $\mathbf{1 4 0}$ & $\mathbf{1 5 0}$ \\
\hline 1 & Sedimen 1 & ++ & ++ & ++ & ++ & ++ & ++ & + & + & + & - & - \\
2 & Sedimen 2 & ++ & ++ & ++ & ++ & ++ & ++ & + & + & + & - & - \\
3 & Sedimen 3 & +++ & +++ & ++ & ++ & ++ & ++ & ++ & + & - & - & - \\
4 & Cair 1 & +++ & +++ & +++ & ++ & ++ & ++ & ++ & + & - & - & - \\
5 & Cair 2 & ++ & ++ & ++ & ++ & ++ & ++ & + & + & + & - & - \\
6 & Cair 3 & +++ & +++ & ++ & ++ & ++ & ++ & ++ & + & - & - & - \\
\hline
\end{tabular}

Tabel 3. Efektivitas bioremediasi merkuri dari tiga sampel

\begin{tabular}{clcccc}
\hline No. & Sampel & $\begin{array}{c}\text { Hg Awal } \\
\text { (ppm) }\end{array}$ & $\begin{array}{c}\text { Hg Akhir } \\
\text { (ppm) }\end{array}$ & Efektivitas & $\begin{array}{c}\text { Efektivitas } \\
\text { Bioremediasi (\%) }\end{array}$ \\
\hline 1 & Sedimen 1 & 130 & 20.5 & 109.5 & 84.23 \\
2 & Sedimen 2 & 130 & 9.8 & 120.2 & 92.46 \\
3 & Cair 2 & 130 & 30.1 & 99.9 & 76.85 \\
\hline
\end{tabular}

Tabel 4. Hasil identifikasi bakteri dengan microbat kit GNB 12 A/12 E

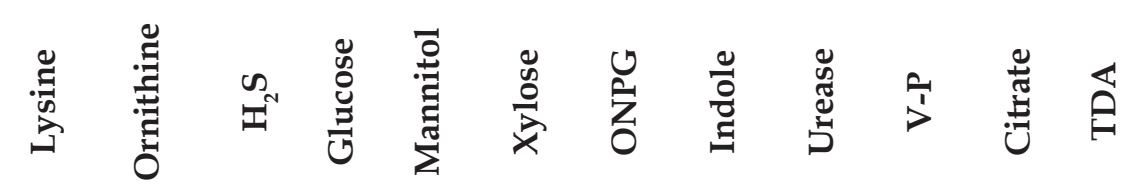

\begin{tabular}{|c|c|c|c|c|c|c|c|c|c|c|c|c|}
\hline Hasil & + & + & - & + & - & + & - & + & + & - & + & + \\
\hline & 4 & 2 & 1 & 4 & 2 & 1 & 4 & 2 & 1 & 4 & 2 & 1 \\
\hline Jumlah & & 6 & & & 5 & & & 3 & & & 3 & \\
\hline Identifikasi & \multicolumn{12}{|c|}{ Morganella morganii $(94,44 \%)$} \\
\hline
\end{tabular}


tinggi dan melebihi ambang batas buangan limbah yang mengandung merkuri oleh Menteri Lingkungan Hidup (2004) ini sangatlah berbahaya bagi lingkungan. Menurut Mieiro et al. (2011), merkuri merupakan salah satu penyebab masalah lingkungan secara global, karena kadar racunnya yang tinggi me nyebabkan beberapa dampak yang berbahaya bagi kesehatan manusia, hewan, serta lingkungan. Berdasarkan Tabel 1, pada parameter hasil analisis kadar merkuri yang ada pada limbah penambangan emas Tumpang pitu, Banyuwangi, kadarnya melebihi ambang batas standar mutu yang telah ditetapkan oleh pemerintah dimana kadar terendah adalah $0.031 \mathrm{ppm}$ pada limbah cair 1 dan yang tertinggi adalah $0.063 \mathrm{ppm}$ pada limbah sedimen 2 .

Limbah sedimen memiliki kadar merkuri yang lebih tinggi bila dibandingkan dengan limbah cair karena pada limbah sedimen logam merkuri yang digunakan akan terakumulasi di dalam tanah dan tidak mampu untuk didegradasi oleh lingkungan sehingga kadarnya akan tinggi. Faktor lainnya yaitu kemampuan mikroorganisme khususnya bakteri yang ada di dalam sedimen dalam mendegradasi logam merkuri yang mempengaruhi tinggi rendahnya kadar merkuri. Kadar yang tinggi dan melebihi ambang batas buangan limbah yang mengandung merkuri oleh Menteri Lingkungan Hidup (2004) ini sangatlah berbahaya bagi lingkungan. Menurut Mieiro et al. (2011), merkuri merupakan salah satu penyebab masalah lingkungan secara global, karena kadar racunnya yang tinggi menyebabkan beberapa dampak yang berbahaya bagi kesehatan manusia, hewan, serta lingkungan.

Pada parameter $\mathrm{pH}$ menunjukkan hasil yang berbeda-beda di setiap sampel. Namun $\mathrm{pH}$ dari keenam sampel tersebut memiliki $\mathrm{pH}$ basa. $\mathrm{pH}$ dari keenam sampel yang diambil dari tiga lokasi tersebut memiliki nilai yang berbeda-beda. Hal ini sesuai dengan penelitian yang dilakukan oleh $\mathrm{Wu}$ et al. (2015), bahwa nilai pH akan selalu bervariasi tergantung dari lokasi pengambilan sampel dan erat kaitannya dengan kondisi lingkungan serta aktivitas mikroba yang ada di dalam sampel. Sampel sedimen memiliki $\mathrm{pH}$ yang cenderung lebih rendah bila dibandingkan dengan sampel cair. Zulfikah et al. (2014) menyatakan bahwa nilai pH sedimen menggambarkan tingkat kemasaman sedimen. Menurut Rembuluwani et al. (2014),
$\mathrm{pH}$ sedimen yang ada di sekitar tambang akan cenderung rendah dibanding dengan sampel cair yang menyebabkan kondisi yang kurang baik bagi tanaman sehingga menyebabkan ketidaksuburan tanah di wilayah pertambangan emas. Menurut Selayar et al. (2015), semakin kecilnya nilai $\mathrm{pH}$ disebabkan semakin besar konsentrasi senyawa yang bersifat asam. Meningkatnya nilai $\mathrm{pH}$ di suatu wilayah ditunjukkan dengan semakin kecilnya kelarutan dari merkuri, sedangkan $\mathrm{pH}$ yang menurun menyebabkan peningkatan kelarutan merkuri yang ada di suatu lingkungan yang menjadikan merkuri akan berubah bentuk menjadi metal merkuri yang memiliki tingkat racun yang lebih tinggi.

Pada parameter warna menunjukkan hasil dimana pada sampel sedimen berwarna coklat sedangkan sampel cair berwarna agak keruh. Warna coklat pada sampel sedimen disebabkan karena limbah sudah bercampur dengan tanah karena mengendap di permukaan tanah, sedangkan sampel cair berwarna agak keruh karena hasil pembuangan limbah emas sudah bercampur dengan beberapa macam bahan yang digunakan dalam proses penambangan emas salah satunya merkuri. Hal ini sesuai dengan Rondonuwu (2012), yang mengatakan bahwa aliran air yang

bercampur dengan bahan lain salah satunya merkuri akan diambil sebagai sampel cair, sedangkan limbah air yang telah bercampur dengan bahan lain, seperti merkuri akan dialirkan ke dalam penampungan. Penampungan tersebut berupa kolam yang sempit sehingga air yang berisi limbah dan logam berbahaya akan meluber ke luar menuju ke tanah disekitar tempat penambangan dan akan mengendap menjadi sedimen. Parameter bau menunjukkan bau lumpur agak menyengat pada sedimen 1,2 , serta pada sampel cair 2. Hal ini menunjukkan bahwa sampel yang memiliki bau agak menyengat disebabkan karena kandungan bahan yang ada di dalamnya. Hal ini terlihat pada Tabel 1, bahwa parameter kandungan merkuri menunjukkan kandungan merkuri tertinggi terdapat pada sampel sedimen 2, dilanjutkan dengan sampel sedimen 1 serta cair 2. Kandungan merkuri yang tinggi dibandingkan dengan sampel yang lain menyebabkan bau yang agak menyengat.

\section{Hasil Isolasi Bakteri Pereduksi Merkuri}

Langkah awal dalam melakukan bioremediasi merkuri adalah melakukan iso- 
lasi bakteri yang bertujuan untuk mendapatkan isolat yang mampu tumbuh di kadar merkuri tinggi. Hasil isolasi bakteri yang diperoleh dari 3 lokasi pengambilan sampel yang terletak di penambangan emas Tumpang Pitu Banyuwangi dapat dilihat pada Tabel 2. Berdasarkan Tabel 2 dapat diketahui bahwa pada media Luria Bertani yang telah ditambahkan merkuri dengan kadar 0 ppm menunjukkan hasil sangat keruh pada sedimen 1,2 , serta cair 2 serta yang lainnya adalah sangat keruh sekali. Hal ini disebabkan karena pada hasil karakteristik sampel di Tabel 1, ketiga sampel tersebut sudah memiliki kandungan merkuri yang tinggi bila dibanding dengan sampel lainnya. Ketika kadar merkuri dinaikkan hingga kadar 50 ppm hasilnya menjadi sangat keruh pada kesemua sampel. Perubahan tersebut karena bakteri yang berada di dalam media LB sudah mulai berkurang kemampuannya untuk hidup di lingkungan dengan kadar merkuri yang lebih tinggi karena pada lingkungan tempat hidupnya kadar merkurinya tidak setinggi kadar merkuri yang ditambahkan pada percobaan. Ketika kadar merkuri dinaikkan menjadi $100 \mathrm{ppm}$, pada sedimen 1,2 , serta cair 2 menunjukkan hasil yang berubah menjadi keruh namun ketika kadar merkuri ditingkatkan menjadi 130 ppm, ketiga sampel yaitu sedimen 1,2 , serta cair 2 yang masih terdapat bakteri di dalamnya dengan hasil yang menunjukkan keruh. Hal ini disebabkan pada kadar ini bakteri indigenous atau bakteri yang berasal dan tinggal dari lingkungan tersebut sudah mampu beradaptasi dengan baik di lingkungan dengan kadar merkuri tinggi. Setelah ditingkatkan menjadi 130 ppm kesemua sampel kecuali sampel cair 2 dan sedimen 1 serta 2 memiliki kadar kekeruhan yaitu keruh. Perbedaan ini disebabkan karena bakteri yang ada pada sampel sedimen 1, 2, dan cair 2 memiliki tingkat adaptasi yang baik karena pada lingkungan awalnya bakteri tersebut sudah lebih resisten dengan merkuri yang memiliki kadar lebih tinggi dibandingkan dengan sampel yang lain. Ketika ditingkatkan lagi menjadi 140-150 ppm, maka media LB-nya menjadi jernih, dengan kata lain sudah tidak ada lagi bakteri yang mampu untuk bertahan hidup di media dengan kadar merkuri sebesar 140 ppm.

\section{Hasil Seleksi Bakteri Pereduksi Merkuri} Seleksi bakteri bertujuan untuk men- dapatkan isolat bakteri terpilih yang mampu untuk hidup di media dengan konsentrasi merkuri tertinggi dan mampu untuk melakukan bioremediasi merkuri. Proses seleksi bakteri pereduksi merkuri dilakukan pada media LB yang telah ditambahkan dengan merkuri konsentrasi merkuri tertinggi yang dapat ditolerir bakteri yaitu sebesar $130 \mathrm{ppm}$. Uji dilakukan pada bakteri yang hidup di konsentrasi merkuri $130 \mathrm{ppm}$ adalah untuk mendapatkan bakteri yang benar-benar resisten merkuri dan mampu untuk melakukan bioremediasi limbah yang mengandung merkuri. Pengajuan dilakukan terhadap tiga sampel yang memiliki potensi bakteri pereduksi merkuri paling baik pada hasil uji isolasi yaitu sedimen 1, 2, serta sampel cair 2 . Hasil pengujian dapat dilihat pada Tabel 3. Pada Tabel 3 dapat dilihat efektivitas bioremediasi merkuri dari ketiga sampel, dimana efektivitas bioremediasi paling tinggi sebesar $92.46 \%$ adalah pada sampel sedimen 2, sedangkan yang terendah adalah sampel cair 2 . Hal ini disebabkan karena pada sampel sedimen 2 memiliki kandungan merkuri yang paling tinggi dibanding dengan sampel yang lain dapat dilihat pada Tabel 1 , sehingga bakteri yang hidup pada sampel sedimen 2 ini merupakan bakteri yang paling resisten.

Hal ini sesuai dengan Dash dan Das (2015), yang menyatakan bahwa penggunaan bakteri indigenous lebih efektif dan lebih murah karena bakteri tersebut mampu untuk melakukan bioremediasi merkuri dengan tingkat efektivitas yang tinggi dibanding bakteri dari luar lingkungan. Setelah dilakukan proses seleksi dan didapatkan bahwa sampel yang memiliki bakteri yang resisten dengan konsentrasi merkuri tinggi serta mampu untuk melakukan degradasi merkuri adalah sampel sedimen 2. Sampel tersebut kemudian dilakukan penuangan di media Luria Agar untuk melakukan proses

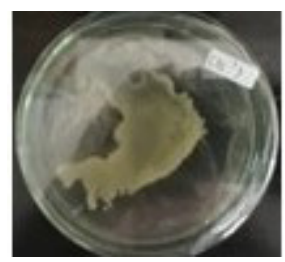

Gambar 1. Isolat bakteri dengan konsentrasi merkuri 130 ppm 
pemurnian bakteri yang ada di dalamnya apabila terdapat bakteri yang beragam. Dari proses pemurnian ternyata hanya terdapat satu koloni bakteri sejenis (Gambar 1).

\section{Hasil Karakterisasi dan Identifikasi Isolat Bakteri}

Setelah mendapatkan isolat murni, kemudian langkah selanjutnya adalah melakukan proses karakterisasi dan identifikasi isolat bakteri. Beberapa pengujian yang dilakukan, salah satunya yaitu uji Gram. Uji Gram dilakukan dengan proses pewarnaan (stain). Tahap ini adalah tahap awal identifikasi bakteri yang betujuan untuk mengetahui warna dan jenis sel bakteri tersebut (Sardiani et al., 2015).

Setelah dilakukan pengujian, didapatkan hasil bahwa bakteri yang berasal dari limbah penambangan emas Tumpang Pitu yang telah dilakukan isolasi, seleksi, dan pemurnian memiliki hasil akhir warna merah. Menurut Dewi (2013), bakteri yang termasuk bakteri Gram positif apabila selnya berwarna keunguan, sedangkan bakteri termasuk jenis Gram negatif apabila selnya berwarna merah. Langkah selanjutnya sebelum dilakukan uji menggunakan kit microbact adalah dilakukan uji oksidase.

Uji ini dilakukan untuk menentukan kit microbact yang akan digunakan. Apabila oksidasenya adalah negatif, maka microbact yang digunakan adalah 12 A. Langkah selanjutnya adalah proses identifikasi menggunakan microbact kit. Microbact kit merupakan suatu kit tambahan untuk identifikasi bakteri berdasarkan perubahan $\mathrm{pH}$ dan penggunaan substrat. Setelah didapatkan jumlah, kemudian dilakukan proses pengecekan menggunakan software microbact (Vithanage et al., 2014). Hasil uji menggunakan microbact dapat dilihat pada Tabel 4 dan diketahui bahwa $94.44 \%$ bakteri yang teridentifikasi merupakan bakteri jenis Morganella morganii. Morganella morganii merupakan bakteri berbentuk batang dan termasuk dalam Gram negatif (Shaaban et al., 2012) yang pertama kali diisolasi oleh Morgan tahun 1907 dari kultur pediatric fecal. Bakteri ini diklasifikasikan sebagai Proteus morganii dan merupakan Genus Morganella. Bakteri ini biasanya banyak ditemukan tersebar di lingkungan dan berada di dalam tubuh manusia maupun hewan khususnya di usus (Liu et al., 2016).

Bakteri jenis ini termasuk dalam family Enterobacteriaceae dan dapat menyebab- kan infeksi bagi manusia (Seija et al., 2015). Sehingga menurut Vinogradof et al. (2015), bakteri ini termasuk pathogen bagi manusia. Ciri dari bakteri Morganella morganii adalah diameter koloni 1-2 mm, berwarna putih keabu-abuan, opaque (tidak tembus cahaya), bentuk lingkaran, convex (cembung), dan lembut, dengan tepian yang rata. Masa inkubasi dari bakteri ini adalah 24 jam dengan suhu optimal $22-35^{\circ} \mathrm{C}$.

Bakteri ini bersifat motil (dapat bergerak) dengan alat gerak berupa flagella, namun beberapa strain tidak dapat membentuk flagella pada suhu di atas $30^{\circ} \mathrm{C}$. Untuk uji urease dan indole adalah positif sedangkan oksidasenya negatif. Asam dan gas juga diproduksi dari pembentukan glukosa. Asam juga diproduksi dari manosa, galaktosa, dan trehalose (Public Health England, 2015).

\section{SIMPULAN}

Berdasarkan penelitian yang telah dilakukan, yang dapat diambil yaitu setelah dilakukan proses isolasi dan identifikasi, dapat diketahui bahwa bakteri yang diisolasi dari limbah penambangan emas Tumpang Pitu, Banyuwangi merupakan bakteri jenis Morganella morganii dan mampu untuk melakukan reduksi merkuri hingga mencapai $92.46 \%$ dimana bakteri ini didapat dari sampel sedimen 2 sehingga bakteri ini berpotensi untuk digunakan sebagai bakteri dalam proses bioremediasi.

\section{DAFTAR PUSTAKA}

Broszeit, S, Hattam, C, Beaumont, N. 2016. Bioremediation of waste under ocean acidification: reviewing the Role of Mytilus edulis. Marine Pollution Bulletin. 103(1):14

Dash, H, R, Das, S. 2015. Bioremediation of Inorganic Mercury Through Volatilization and Biosorption by Transgenic Bacillus cereus BW-03( $\left.{ }_{\mathrm{P}} \mathrm{PW}-05\right)$. International Biodeterioration and Biodegradation. 103:179-185 
Dash, H, R, Sahu, M, Mallick, B, Das, S. 2017. Functional efficiency of MerA protein among diverse mercury resistant bacteria for efficient use in bioremediation of inorganic mercury. Biochimie. 142:207-215

Davies, G, R. 2014. A toxic free future: is there a role for alternatives to mercury in small-scale gold mining?. Futures. 62:113-119

Dewi, A, K. 2013. Isolasi, identifikasi dan uji sensitivitas Staphylococcus aureus terhadap Amoxicillin dari sampel susu kambing peranakan ettawa (PE) penderita mastitis di wilayah girimulyo, kulonprogo, yogyakarta. Jurnal Sain Veteriner. 31(2):138-150

Fachri, F. 2005. Aplikasi kriging sekuensial pada penaksiran cadangan emas. Jurnal Gradien. 1(1):34-37

Rifai-Hasan, P, A. 2009. Development, power, and the mining industry in papua: a study of freeport indonesia. Journal of Business Ethics. 89(Supplement 2):129143

Hamann, C, R, Boonchai, W, Wen, L, Sakanashi, E, N, Yu Chu, C, Hamann, K, Hamann MD, C, P, Sinniah, K, Hamann, D. 2014. Spectrometric analysis of mercury content in 549 skin-lightening products: Is mercury toxicity a hidden global health hazard?. Journal of the American Academy of Dermatology. 70(2):281-287

Hema, T, G, Getha, K, Tan, G, Y, A, Sahira, H, L, Syamil, A, M, Fairuz, M, Y, N. 2014. Actinobacteria isolates from tin tailings and forest soil for bioremediation of heavy metals. Journal of Tropical Forest Science. 26(1):153-162

Huber, J, Leopold, K. 2016. Nanomaterialbased strategies for enhanced mercury trace analysis in environmental and drinking waters. TrAC Trends in Analytical Chemistry. 80:280-292

Karmanto, Kencanawati, D, Adlan, M. 2013. Menimbang Masa Depan Bisnis Tambang. Media Penilai, Jakarta

Kim, J, H, Lee, S, J, Kim, S, Y, Choi, G, Lee, J, J, Kim, H, J, Kim, S, Park, J, Moon, H, B, Choi, K, Kim, S, Choi, S, R. 2016. Association of food consumption during pregnancy with mercury and lead levels in cord blood. Science of The Total Environment. 563-564:118-124

Kocman, D, Kanduč, T, Ogrinc, N, Horvat,
M. 2011. Distribution and partitioning of mercury in a river catchment impacted by former mercury mining activity. Biogeochemistry. 104(1-3):183-201

Kurniati, E, Arfarita, N, Imai, T, Higuchi, T, Kanno, A, Yamamoto, K, Sekine, M. 2014. Potential bioremediation of mercury-contaminated substrate using filamentous fungi isolated from forest soil. Journal of Environmental Sciences. 26(6):1223-1231

Liu, H, Zhu, J, Hu, Q, Rao, X. 2016. Morganella Morganii, a non-negligent opportunistic pathogen. Int. J. Infect Dis. 50:10-17

Mahbub, K, R, Krishnan, K, Megharaj, M, Naidu, R. 2016. Bioremediation potential of a highly mercury resistant bacterial Strain Sphingobium SA2 isolated from contaminated soil. Chemosphere. 144:330-337

Ma, F, Sun, M, Yuan, C, Yao, J, Wang, S. 2014. A novel fluorescent sensor for the sensitive detection of mercury. APCBEE Procedia. 10:12-15

McCarthy, D, Edwards, G, C, Gustin, M, S, Care, A, Miller, M, B, Sunna, A. 2017. An innovative approach to bioremediation of mercury contaminated soils from industrial mining operations. Chemosphere. 184:694-699

Menteri Lingkungan Hidup. 2004. Peraturan Menteri Negara Lingkungan Hidup Nomer 51 Tahun 2004. Dilihat 26 Agustus 2018. <http://www. ppk-kp3k.kkp.go.id/ver3/media/ download/RE_keputusan-menterinegara-lingkungan-hidup-nomor51-tahun-2004_20141008143942.pdf>

Mieiro, C, L, Pacheco, M, Duarte, A, C, Pereira, M, E. 2011. Fish consumption and risk of contamination by mercury - considerations on the definition of edible parts based on the case study of european sea bass. Marine Pollution Bulletin. 62(12):2850-2853

Molamohyeddin, N, Ghafaourian, H, Sadatipour, S, M. 2017. Contamination assessment of mercury, lead, cadmium and arsenic in surface sediments of chabahar Bay. Marine Pollution Bulletin. 124(1):521-525

Morgan, H, R. 1907. Upon the bacteriology of the summer diarrhoea of infants. $\mathrm{Br}$ Med J. 2:908-12

Nasikhin, R, Shovitri, M. 2013. Isolasi dan karakterisasi bakteri pendegradasi so- 
lar dan bensin dari pelabuhan gresik. Jurnal Sains dan Seni ITS. 2(2):2337-3520

Neneng, L, Tanduh, Y, Saraswati, D. 2012. Aplikasi metode reklamasi terpadu untuk memperbaiki kondisi fisik, kimiawi, dan biologis, pada lahan pasca penambangan emas di kalimantan tengah. Prosiding Insinas, IPB, Bogor, pp. $81-85$

Oliveira, C, S, Oliveira, V, A, Costa, L, M, Pedroso, T, F, Fonseca, M, M, Bernatdi, J, S, Fiuza, T, L, Pereira, M, E. 2016. Inorganic mercury exposure in drinking water alters essential metal homeostasis in pregnant rats without altering rat pup behavior. Reproductive Toxicology. 65:18-23

Pepi, M, Gaggi, C, Bernardini, E, Focardi, S, Lobianco, A, Ruta, M, Nicolardi, V, Volterrani, M, Gasperini, S, Trinchera, G, Renzi, P, Gabellini, M, Focardi, S, E. 2011. International Biodeterioration $\mathcal{E}$ Biodegradation. 65(1):85-91

Peng, Y, Deng, A, Gong, X, Li, X, Zhang, Y. 2017. Coupling process study of lipid production and mercury bioremediation by biomimetic mineralized microalgae. Bioresource Technology. 243:628633

Public Health England. 2015. UK standards for microbiology investigations identification of Enterobacteriaceae. Dilihat 25 Oktober 2017. < https:/ / assets.publishing.service.gov.uk/government/ uploads/system/uploads/attachment_data/file/423601/ID_16i4.pdf>

Rembuluwani, N, Dacosta, F, A, Gumbo, J, R. 2014. Environmental risk assessment and risk management strategies for abandoned new union gold mine in malamulele, limpopo, south africa. An Interdisciplinary Response to Mine Water Challenges - Sui, Sun E Wang (eds). 367373

Rondonuwu, SB. 2012. Bioremediasi Limbah Mengandung Merkuri Menggunakan Bakteri Tempatan dengan Sistem Bioreaktor dan Lahan Basah Buatan. Tesis. IPB. Bogor

Sardiani, N, Litaay, M, Budji, R, G, Priosambodo, D, Syahribulan, Dwyana, Z. 2015. Potensi tunikata Rhopalaea $s p$ sebagai sumber inokulum bakteri endosimbion penghasil antibakteri; 1 . karakterisasi isolat. Jurnal Alam dan Lingkungan. 6(11):1-10
Selayar, N, A, Tumembouw, S, Mondoringin, L, J, J. 2015. Telaah kandungan logam berat merkuri $(\mathrm{Hg})$ di sekitar teluk manado. Jurnal Budidaya Perairan. 3(1):124-130

Setiawan, C. 2017. Menyingkap harta tersembunyi di pantai prigi, kabupaten trenggalek. Dilihat 30 Oktober 2017. < http://suarageologi.blogspot. co.id/2015/04/menyingkap-hartatersembunyi-di-pantai-prigi-kabupaten-trenggalek.html>

Shaaban, M, T, Ghozlan, H, A, Maghraby, M, M, E. 2012. Susceptibility of bacteria infecting urinary tract to some antibiotics and essential oils. Journal of Applied Pharmaceutical Science. 2(4):90-98

Sharma, B, Dangi, A, K, Shukla, P. 2018. Contemporary enzyme based technologies for bioremediation: a review. Journal of Environmental Management. 210:10-22

Seija, V, Presentado, J, C, M, Bado, I, Ezdra, R, P, Batista, N, Gutierrez, C, Guirado, M, Vidal, M, Nin, M, Vignoli, R. 2015. Sepsis caused by new delhi metallo- $\beta$ lactamase (blaNDM-1) and qnrD-producing Morganella morganii, treated successfully with fosfomycin and meropenem: case report and literature review. International Journal of Infectious Diseases. 30:20-26

Sinha, S, N, Paul, D. 2014. Heavy metal tolerance and accumulation by bacterial strains isolated from waste water. J. Chem. Biol. Phys. Sci. 4:812-817

Siahaan, B, C, Utami, S, R, Handayanto, E. 2014. Fitoremediasi tanah tercemar merkuri menggunakan Lindernia Crustacea, Digitaria Radicosa, dan Cyperus Rotundus serta pengaruhnya terhadap pertumbuhan dan produksi tanaman jagung. Jurnal Tanah dan Sumberdaya Lahan. 1(2):35-51

Supit, J, M. 2009. Estimasi cadangan tereka emas sekunder pada KP PT indonesia timur raya nabire papua. Istech. 1(1)

Vinogradof, E, Nash, J, H, Foote, S, Young, N, M. 2015. The structure of the Morganella Morganii lipopolysaccharide core region and identification of its genomic loci. Carbohydr. Res. 402:232-235

Vithanage, N, R, Yeager, T, R, Jadhav, S, R, Palombo, E, A, Datta, N. 2014. Comparison of identification systems for psychotrophic bacteria isolated from raw bovine milk. Int. J. Food. Microbiol. 189(1):26-38 
Jurnal Teknologi Pertanian Vol. 19 No. 1 [April 2018] 15-24

Bioremediasi Merkuri Menggunakan Bakteri Indigenous [Lutfi dkk]

Wu, H, Huo, Y, Zu, M, Hu, M, Wei, Z, He, P. 2015. Eutrophication assessment and bioremediation strategy using seaweeds co-cultured with aquatic animals in an enclosed bay in china. Mar. Pollut Bull. 95(1):342-349
Zulfikah, Z, Basir, M, Isrun, B. 2014. Konsentrasi merkuri $(\mathrm{Hg})$ dalam tanah dan jaringan tanaman kangkung (Ipomoea Reptans) yang diberi bokashi kirinyu (Chromolaena Odorata L.) pada limbah tailing penambangan emas poboya kota palu. Agrotekbis. 2(6):587-595 